\title{
Rancang Bangun Sistem Informasi Akademik (SIAKAD) dengan Integrated Online Registration System pada Unit Laboratorium dan Praktikum Pada Fakultas Ilmu Tarbiyah dan Keguruan IAIN Surakarta
}

\author{
*Rochmat Budi Santosa, Novianni Anggraini \\ UIN Raden Mas Said Surakarta, Indonesia \\ Corresponding email: santosabudi21@gmail.com
}

Sejarah Artikel

Dikirim: November 2021

Diterima: Desember 2021

Dipublikasi: Desember 2021

\section{Kata Kunci}

IAIN Surakarta; rancang bangun; siakad

\begin{abstract}
Abstrak
Untuk menyusun rancangan aplikasi online registration system yang terintegrasi dengan SIAKAD, dilakukan berbagai kegiatan yang dikelola oleh Unit Laboratorium dan Praktikum di Fakultas Ilmu Tarbiyah dan Keguruan IAIN Surakarta. Penelitian ini mengadopsi model dari Borg (2007). Adapun prosedur pengembanganya dimulai dari analisis kebutuhan, Perencanaan, Pengembangan Form Product, Pengujian Lapangan Awal, Revisi Produk Utama, dan Pengajian Lapangan Utama. Penelitian dilaksanakan di Fakultas Ilmu Tarbiyah dan Keguruan IAIN Surakarta. Untuk analisis data digunakan 2 cara yaitu teknik induksi pada tahap need analysis, dan interactive model milik Miles dan Huberman untuk data hasil wawancara dan uji ahli. Keabsahan data sendiri dilakukan melalui triangulasi sumber dan metode. Hasil analisis data menunjukkan bahwa (1) On line Registration adalah model aplikasi pendaftaran yang lebih efektif untuk mahasiswa dan Unit Laboratrium dan Praktikum FITK IAIN Surakarta, (2) Online Registration System yang menjadi salah satu fitur baru dalam SIAKAD diproyeksikan sebagai salah satu fitur yang akan mempermudah layanan pada mahasiswa terkait pendaftaran sebagai calon peserta praktikan, dan (3) Disamping itu melalui layanan SIAKAD mahasiswa juga akan lebih mudah dan efektif dalam mencari informasi terbaru dari seluruh civitas akademika di lingkungan FITK khususnya yang terkait dengan kegiatan di Unit Laboratorium dan Praktikum.
\end{abstract}

\section{Design of an Academic Information System (SIAKAD) with an Integrated Online Registration System at the Laboratory and Practicum Unit at the Faculty of Tarbiyah and Teacher Training IAIN Surakarta}

\section{Article History}

Received: November 2021

Accepted: December 2021

Published: December 2021

Key Words

IAIN Surakarta;

online registration system; siakad
Abstract

To develop an online registration system that is integrated with SIAKAD, various activities are managed by the Laboratory and Practical Unit at IAIN Surakarta Faculty of Teacher Training. This study adopted a model from Borg (2007). The development procedure starts from the needs analysis, Planning, Product Form Development, Initial Field Testing, Main Product Revision, and Main Field Study. The research was conducted at the IAIN Surakarta Faculty of Teacher Training. The data analysis used two ways, namely induction techniques in the stage of need analysis, and interactive models belonging to Miles and Huberman for interview data and expert tests. The validity of the data is done through source triangulation and methods. The results of data analysis indicate that (1) Online registration is a more effective registration application model for students admitted in Laboratory and Practicum Unit, (2) Online Registration System projected as one of the features that will facilitate services for students related to registration as prospective participants, and (3) it is easier and more effective for students to find the latest information from all academics in the faculty environment especially those related to activities in the Laboratory and Practicum Units. 


\section{PENDAHULUAN}

Perkembangan teknologi dan informasi yang semakin pesat di dunia memaksa berbagai pihak untuk memanfaatkannya diberbagai hal tak terkecuali lembaga pendidikan. Perguruan tinggi sebagai salah satu lembaga pendidikan formal wajib meningkatkan mutu dosen, lembaga maupun sarana dan prasarana guna menunjang proses pembelajaran dan pelayanan kepada mahasiswa. Perguruan tinggi saat ini membutuhkan layanan pendidikan yang terkomputerisasi, kemudahaan dalam mendapatkan informasi yang cepat diakses, dan juga sistem yang terintegrasi sehingga dapat meningkatkan kinerja, kualitas dalam pelayaanan, dan daya saing.

SIAKAD (Sistem Informasi Akademik) pertama kali diperkenalkan di IAIN Surakarta pada tahu 2011. Diawal pembuatan SIAKAD hanya mempunyai fitur yang belum banyak namun seiiring perjalanan waktu penggunaaan SIAKAD lebih berkembangantara lain; memuat berita kampus, perkuliahan, informasi mahasiswa, jurnal, kalender akademik dan alumni. Secara resmi SIAKAD digunakan pada tahun 2012 tujuan digunakannya SIAKAD di IAIN Surakarta Di FITK sendiri penggunaaan SIAKAD digunakan untuk memuat berita kampus, informasi perkuliahan, pengambilan mata kuliah (KRS), pengelolaan data mahasiswa dan dosen, jurnal mengajar dosen dan lain-lain.

Penelitian mengenai penerapan SIAKAD pernah dilakukan di antaranya oleh Wicaksono (2014) tentang penjadwalan perkuliahan di SIAKAD. Hasil penelitiannya menemukna bahwa jika penjadwalan perkuliahan dilakukan dengan cara manual tentu saja akan memakan waktu cukup lama, maka perlu dilakukan pendekatan menggunakan evolutionary algorithm untuk mempermudah dalam pembuatan jadwal kuliah dengan menerapkan aturan yang berlaku. Penyusunan kromosom dilakukan dalam bentuk representasi string yakni berupa susunan menu yang mewakili hari, jam perkuliahan, ruang dan gedung (Wicaksono, 2014).

Selain itu, Muhammad melakukan penelitian dengan menerapkan metode IT Balanced Scorecard yang dapat digunakan sebagai kerangka kerja untuk mengevaluasi kinerja sistem informasi akademik di perguruan tinggi, Evaluasi yang dia lakukan diyakini sangat bermanfaat untuk memberikan umpan balik bagi manajemen di Universitas Serambi Mekkah, khususnya untuk mengetahui sejauh mana kinerja sistem informasi yang sudah digunakan yang direspon oleh operator sistem dan bagaimana tanggapan operator sistem berdasarkan perspektif IT BSC, skor pencapaian masing-masing indikator kinerja yang telah didapat memperjelas kontribusi sistem informasi akademik dalam mendukung tujuan strategi institusi (Muhammad, 2018).

Berdasarkan berbagai pertimbangan, artikel ini menjabarkan rancangan aplikasi online registration system yang terintegrasi dengan SIAKAD dalam berbagai kegiatan yang dikelola oleh Unit Laboratorium dan Praktikum di Fakultas Ilmu Tarbiyah dan Keguruan IAIN Surakarta.

\section{METODE}

Berdasarkan masalah yang diajukan, penelitian ini adalah penelitian pengembangan (Research and Development) dengan tujuan adalah untuk mendesain sebuah aplikasi baru untuk mendukung online regestration yang terintegrasi dengan SIAKAD. Metode penelitian dan pengembangan yang digunakan adalah metode dari Gall, Gall, \&Berg 
(2007) yang menyatakan bahwa penelitian Research and Development adalah model yang hasil temuan dari penelitian akan digunakan untuk mendesain produk dan prosedur baru yang secara sistematis diujikan di lapangan, dievaluasi, diperbaiki hingga mencapai kriteria standar keefektifan dan kualitas.

Dalam penelitian ini peneliti mengadipsi model dari Borg (2007). Adapun prosedur pengembanganya dimulai dari analisis kebutuhan, Perencanaan, Pengembangan Form Product, Pengujian Lapangan Awal, Revisi Produk Utama, dan Pengajian Lapangan Utama. Penelitian dilaksanakan di Fakultas Ilmu Tarbiyah dan Keguruan IAIN Surakarta. Waktu penelitian adalah Juni 2018 sampai dengan September 2018.

Peneliti menggunakan teknik pengumpulan data yaitu data kualitatif. Data kualitatif diadapatkan dari wawancara dengan mahasiswa, FGD dengan pakar aplikasi, Unit Laboratorium dan Praktikum dan study pustaka dan juga didapatkan dari catatan validasi ahli dalam tahapan planning, revisi dan finalisasi produk aplikasi. Masukan atau review dari para ahli ini juga digunakan untuk mengumpilkan informasi tentang validasi produk aplikasi. Key instrument dari penelitian ini adalah peneliti sendiri yang terdiri dari ketua yang dibantu oleh 1 orang anggota dan 2 orang pembantu peneliti.

Untuk analisis data digunakan 2 cara yaitu teknik induksi pada tahap need analysis, dan interactive model milik Miles dan Huberman untuk data hasil wawancara dan uji ahli. Keabsahan data sendiri dilakukan melalui triangulasi sumber dan metode.

\section{Prosedur Penelitian}

Penerapan aplikasi online registration yang diintegrasikan dengan SIAKAD yang dilakukan dengan mengadopsi model dari Borg (2007). Adapun prosedur pengembangnya adalah sebagai berikut:

\section{Analisis Kebutuhan}

Dalam langkah ini analisis kebutuhan dimulai dari interview dan FGD dan juga dokumen hasil penelitian yang relevan yang kemudian dilanjutkan dengan melakukan penitian awal. Dalam tahapa/ langkah ini peneliti mengumpulkan informasi untuk analissi kebutuhan mengenai model aplikasi online registration yang diintegrasikan dengan SIAKAD yang akan dirancang untuk pengembangan SIAKAD sendiri.dalam tahap ini peneliti berdiskusi dengan PTIPD dan juga pakar aplikasi yang sangat memahami SIAKAD khususnya di IAIN Surakarta. Metode pengumpulan data yang dipakai dalam penelitian ini adalah pedoman wawancara dan juga Forum Group Discussion. Data yang diperoleh kemudian dianalisis secara deskriptif. Dari awal penelitian menunjukkan bahwa perlu sebuah aplikasi pendaftaran online yang bisa diintegrasikan dengan SIAKAD. Disamping itu wawancara juga dilakukan dengan para pengguna pendaftran online yaitu mahasiswa yang akan mengikuti kegiatan praktikum yang menguatkan data bahwa perlunya pengembangan tambahan aplikasi di SIAKAD yang memungkinkan mereka mengkases pendaftaran secara online. Dari informasi inilah dapat ditarik kesimpulan perlunya tambahan aplikasi baru yang dikembangkan, revisi produk aplikasi, uji coba awal aplikasi, produk akhir aplikasi dan juga sosialisasi produk aplikasi.

\section{Planning (Perencanaan)}

Dalam tahap perencanaan, peneliti mempersiapkan prototype aplikasi online registation system yang akan diintegrasikan dengan SIAKAD. Dalam hal ini peneliti menggunakan bantuan pakar terutama pakar aplikasi dan juga PTIPD.

\section{Revisi Produk Aplikasi}

Dalam tahap ini dilakukan revisi pada prototipe yang sudah diuji coba dikalangan terbatas. Dari hasil uji coba terbatas inilah diperoleh iformasi apakah aplikasi yang baru ini memiliki keberhasilan atau tidak. 


\section{Finalisasi Aplikasi}

Dalam tahapan ini uji coba dilakukan dengan menggunakan subject peneltian yaitu mahasiswa semester 5 yang akan berpartisipasi dalam tryout produk baru yang akan dikembangkan. Para respondent diminta menggunakan aplikasi baru yang telah dibuat dan mengevaluasi aplikasi tersebut

\section{HASIL DAN PEMBAHASAN \\ Desain Awal Produk}

Hasil desain awal produk aplikasi ini merupakan hasil serangkain prosedur yaitu Analisis Kebutuhan, Perencanaan, Pengembangan format produk awal, Validasi produk awal, Revisi produk awal.

\section{Analisis kebutuhan}

Di awal penelitan ini, peneiti melakukan review pustaka dan need analysis tentang kebutuhan aplikasi untuk online registration system yang bisa diintegrasikan dengan SIAKAD. Kegiatan awal diawali dengan mencermati SIAKAD beserta fitur-fiturnya yang selama ini digunakan di Fakultas Ilmu Tarbiyah dan Keguruan IAIN Surakarta. Selanjutnya peneliti mendiskusikan dengan co-reseacher tentang tujuan awal dan utama dari pembuatan aplikasi online registration system yang bisa diintegrasikan dengan SIAKAD terutama untuk mempermudah mahasiswa dalam proses pendaftaran kegiatan praktik yang dikelola oleh Unit Laboratorium dan Praktikum seperti kegiatan Magang 1, 2 dan 3. Selama ini para calon peserta kegiatan Magang biasanya menndaftarkan diri secara manual dengan mengunduh form pendaftaran di SIAKAD. Hal ini dirasa kurang efektif dan efisien. Didalam proses ini dihasilkan rumusan tujuan utama yang merancang sebuah aplikasi yang bisa diitegrasikan dengan SIAKAD sehingga mahasiswa bisa melakukan pendaftaran secara online dari mana saja dan kapan saja.

\section{Perencanaan}

Perencanaan yang dilakukan peneliti bersama co-reseacrher dilakukan dengan perumusan tujuan-tujuan khusus dari pengembangan fungsi SIAKAD dengan mengembangkan sebuah aplikasi baru yang dapat membantu dan memudahkan layanan pada mahasiswa.

1. Tujuan aplikasi sebagai sarana yang bisa digunakan dalam online registration system dalam proses pendaftaran kegiatan praktik mahasiswa di Fakultas Ilmu tarbiyah dan Keguruan.

2. Masalah pendaftaran mahasiswa yang akan mendaftar kegiatan praktikum seperti Magang 1, 2 dan 3.

3. Peran aplikasi online registration system sebagai cara yang lebih mudah bagi mahasiswa dalam proses pendaftaran kegiatan praktik yang diselenggarakan di fakultas melalui unit laboratorium dan praktikum FITK IAIN Surakarta dan cara menggunakan aplikasi online registration system yang dintegrasikan dengan SIAKAD.

4. Masalah IT dan koneksi internet dalam layanan SIAKAD yang selama ini digunakan oleh mahasiswa di Fakultas Ilmu Tarbiyah dan Keguruan IAIN Surakarta.

Daftar tersebut digunakan sebagai panduan untuk menentukan tujuan khusus melalui kegiatan studi dari bidang terkait berikut.

1. Mencermati SIAKAD beserta fungsi dan layanan yang bisa digunakan oleh mahasiswa dan dosen selama ini dan membuat catatan-catatan penting yang bisa melengkapi kekurangan layanan terkait SIAKAD yang ada.

2. Mencermati tujuan awal penggunaan SIAKAD. 
3. Mencermati kelemahan dan kelebihan fitur layan SIAKAD yang digunakan di Fakultas

4. Mencermati literartur tentang pembuatan aplikasi yang bisa diaplikasikan dengan SIAKAD.

Dari pencarian informasi dari sumber yang dipandu dengan daftar chek list kebutuhan diatas diperoleh informasi sebagai berikut.

1. Tujuan-tujuan aplikasi online registration system dalam proses pendaftaran peserta praktik yang diselenggarakan oleh fakultas melalui Unit Laboratorium dan Praktikum FITK IAIN Surakarta.

2. Online registration system sebagai fitur tambahan dalam SIAKAD untuk pelayanan mahasiswa dalam proses pendaftaran peserta kegiatan praktik

Tujuan online registration system sebagai fitur tambahan dalam SIAKAD untuk pelayanan mahasiswa dalam proses pendaftaran peserta kegiatan praktik sebagai adalah memudahkan mahasiswa yang akan mendaftar sebagai peserta kegiatan praktik yang diselenggarakan oleh fakultas melalui Unit Laboratorium dan Praktikum. Didalam buku panduan disebutkan bahwa sebelum mahasiswa mengikuti kegiatan praktikum seperti Magang 1, 2, dan 3 maka mahasiswa wajib mendaftar sebagai calon peserta dengan memenuhi persyaratan yang sudah ditetapkan oleh Fakultas. Adapun persyaratannya antara lain adalah calon peserta harus sudah menempuh dan lulus beberapa mata kuliah yang menjadi prasyarat. Mata kuliah yangdijadikan prasyarat dari masing-masing Program Studi berbeda-beda. Disamping itu juga mahasiswa sudah harus menempuh dan lulus dalam beberapa kegiatan akademik lainnya seperti lulus P3KMI dan SKL Ibadah. Ini berarti bahwa aplikasi online registration system dibutuhkan untuk memudahkan calon peserta kegiatan praktik agar lebih mudah dan efektif dalam proses pendaftaran calon peserta. Hal ini juga untuk lebih memudahkan pengelola Unit Laboratorium dan Praktikum dalam mendata peserta yang akan mengikuti kegiatan praktik. Ini juga dikarenakan waktu yang singkat dalam proses pendaftaran dan verifikasi calon peserta kegiatan praktik.

\section{Menambah fitur aplikasi di SIAKAD}

Dalam buku paduan disebutkan bahwa kegiatan praktikum mahasiswa yang dilaksanakan oleh Unit Laboratorium dan Praktikum adalah Kegiatan Magang 1, 2 dan 3. Adapun tujuan dari kegiatan Magang 1 beserta prasyaratnya dari masing-masing Prodi berbeda-beda. Fitur baru di SIAKAD memungkinkan mahasiswa calon peserta magang bisa mendaftar online Sehingga pendaftaran magang dengan prasyarat bisa lebih efektif dan efisien. Ini menunjukkan bahwa aplikasi online registration system sangat dibutuhkan untuk menambah 1 fitur di SIAKAD guna mempermudah kegiatan pendaftran mahasiswa sebagai calon peserta kegiatan magang serta membantu pengelola Unit Laboratorium dan Praktikum dalam bekerja dengan waktu yang lebih efektif dan efisien serta akurat dalam proses pendaftaran peserta praktik di Fakultas Ilmu Tarbiyah dan Keguruan IAIN Surakarta.

\section{Alur Proses Pendaftaran Peserta Kegiatan Praktikum}

Dalam penelitian ini peneliti membaca alur proses pendaftaran kegiatan Praktikum mahasiswa di lingkungan FITK khususnya kegiatan Magang 1, 2 ,dan 3. Adapun salah syarat dalam pendaftaran kegiatan tersebut adalah menggunakan prasyarat telah ditempuhnya beberapa mata kuliah di masing-masing Program Studi.

Adapun syarat-syarat Magang sendiri pada masing-masing Prodi berbeda-beda. Untuk prodi PAI (Pendidikan Agama Islam), mahasiswa harus telah menempuh dan mendapat verifikasi dari panitia pada mata kuliah berikut: a) Ilmu Pendidikan Islam, b) 
Metodologi PAI, c) Pengembangan Sistem Evaluasi PAI, d) Media Pembelajaran PAI, e) Psikologi Pendidikan, f) Pengembangan Kurikulum PAI, g) Materi PAI, dan h) Perencanaan Sistem Pembelajaran PAI.

Untuk prodi PBA (Pendidikan Bahasa Arab), mahasiswa harus telah menempuh dan mendapat verifikasi dari panitia pada mata kuliah berikut: a) Metodologi PBA 1, b) Pengembangan Sistem Evaluasi PBA 1, c) Perencanaan sistem PBA, d) Muhadatsah 2, e) Qiro'ah 2, f) Insya' I, g) Sharf 2, dan h) Nahwu 2.

Untuk prodi PBI (Pendidikan Bahasa Inggris), mahasiswa harus telah menempuh dan mendapat verifikasi dari panitia pada mata kuliah berikut: a) Pengembangan Peserta Didik, b) Advanced English Grammar, c) Argumentative Essay Writing / Writing For Academic Purposes, d) Critical Reading 2 / Academic Reading, e) Public Speaking / Speaking For Academic Purposes, f) TEFL Approaches, dan g) Curriculum Material Development.

Untuk prodi PIAUD (Pendidikan Anak Usia Dini), mahasiswa harus telah menempuh dan mendapat verifikasi dari panitia pada mata kuliah berikut: a) Ilmu Pendidikan Islam, b) Psikologi Perkembangan Anak, c) Pengembangan Kurikulum RA,d) Perencanaan Pembelajaran di RA, e) Media Pembelajaran AUD, f) Pengembangan Bahan Ajar AUD, dan g) Evaluasi Pembelajaran AUD.

Untuk prodi PGMI (Pendidikan Guru Madrasah Ibtidaiyah), mahasiswa harus telah menempuh dan mendapat verifikasi dari panitia pada mata kuliah berikut: a) Ilmu Pendidikan Islam, b) Pengembangan Kurikulum MI, c) Analisis Kurikulum MI, d) Media Pembelajaran, e) Strategi Pembelajaran 1, dan f) Strategi Pembelajaran 2.

Sedangkan untuk prodi TBI (Tadris Bahasa Indonesia), mahasiswa harus telah menempuh dan mendapat verifikasi dari panitia pada mata kuliah berikut: a) Pengantar Pendidikan, b) Profesi Kependidikan, c) Perkembagan Peserta Didik, d) Pengembagan Kurikulum dan Silabus, e) Kajian Buku Teks Bahasa Indonesia, f) Perencanaan Pengajaran, g) Metode Pembelajaran Bahasa dan Sastra, dan h) Manajemen Pendidikan. Selain sudah mengikuti mata kuliah yang tersebut di atas, mahasiswa dari semua prodi juga sudah harus mengikuti program dari fakultas dan jurusan sebagai berikut: a) P3KMI dan b) Praktik Keahlian.

Fungsi baru dari aplikasi online registration system sebagai tambahan fitur yang diintegrasikan dengan SIAKAD dan cara menggunakan fitur tersebut dalam proses pendaftaran sebagai peserta kegiatan praktikum.

Fitur yang baru diharapkan bisa menjadi supporting system dalam proses pendaftaran peserta kegiatan praktikum terutama Magang1, 2, dan 3. Melalui fitur baru ini dapat digunakan oleh calon peserta kegiatan praktikum sebagai salah satu layanan yang memudahkan mereka mendaftar dari berbagai tempat dan waktu yang berbeda.Pendaftaran ini menggunakan fitur yang langsung diitegrasikan dengan SIAKAD. Para calon peserta kegiatan praktikum membuka fitur layanan pendaftaran dengan sebelumnya membuka halaman SIAKAD yang kemudian menggunakan personal ID atau user serta password sendiri-sendiri. Kemudian memilih fitur pendaftaran peserta praktikum Magang 1, 2 atau 3. Berikutnya setelah selesai mahasiswa/ calon peserta praktikum mendaftar, admin akan memverifikasi data tersebut. Dari tujuan utama diatas dapat diperkirakan bahwa fitur aplikasi online registration system harus langsung diintegrasikan dengan SIAKAD sehingga membutuhkan aplikasi yang betul-betul bisa diaplikasikan bersama dengan SIAKAD.

\section{Pengembangan format produk awal}

Format produk awal aplikasi online registration system ini dikembangkan dari hasil perencanaan. Adapun format produk awal bisa dilihat dari penjelasan berikut: fitur yang 
akan diakses mahasiswa sebagai calon peserta kegiatan praktikum harus melalui akun SIAKAD yang hanya bisa diakses masingmasing mahasiswa melalui ID/ User serta password masing-masing. Menu tampilan SIAKAD dari halam awal adalah sebagai berikut.



Gambar 1. Tampilan Awal SIAKAD

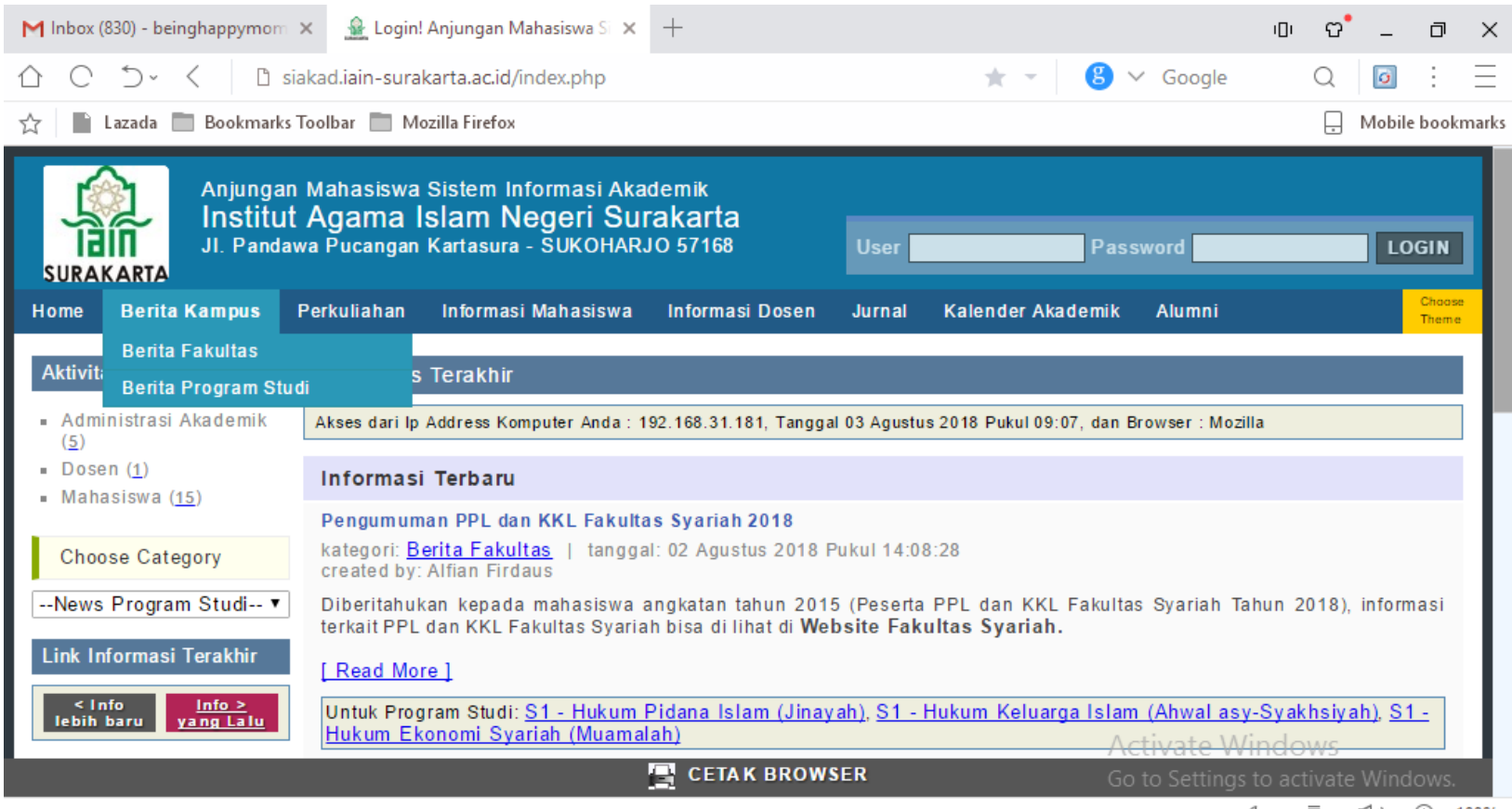

siakad.iain-surakarta.ac.id/index.php/news/berita-kampus-UGF6OFIOeC91LzhqTmgvKOJveEkxbFVJPTNNQWFobG9FVmdJVWMrZFVxL2g=

\# Search the web and Windows

ए]

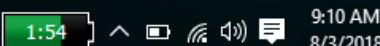

Gambar 2. Tampilan Beranda Berita Kampus berisi Berita Fakultas dan Berita Program Studi 

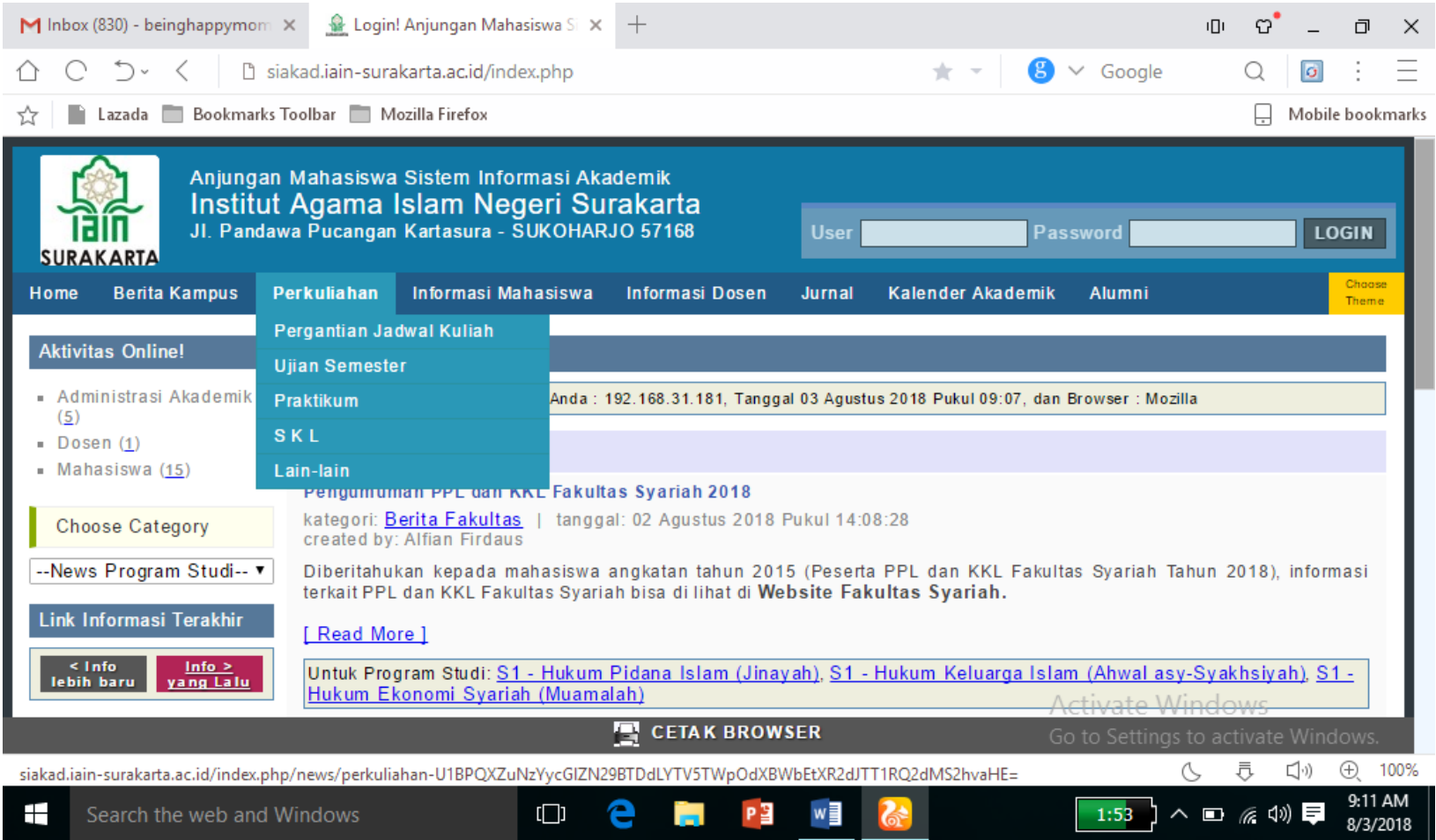

Gambar 3. Tampilan Beranda Perkuliahan BERISI Pergantian Jadwal Kuliah, Ujian Semester, Praktikum, SKL, dll

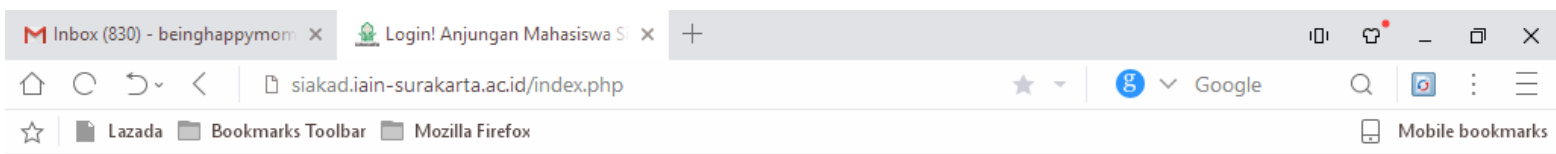

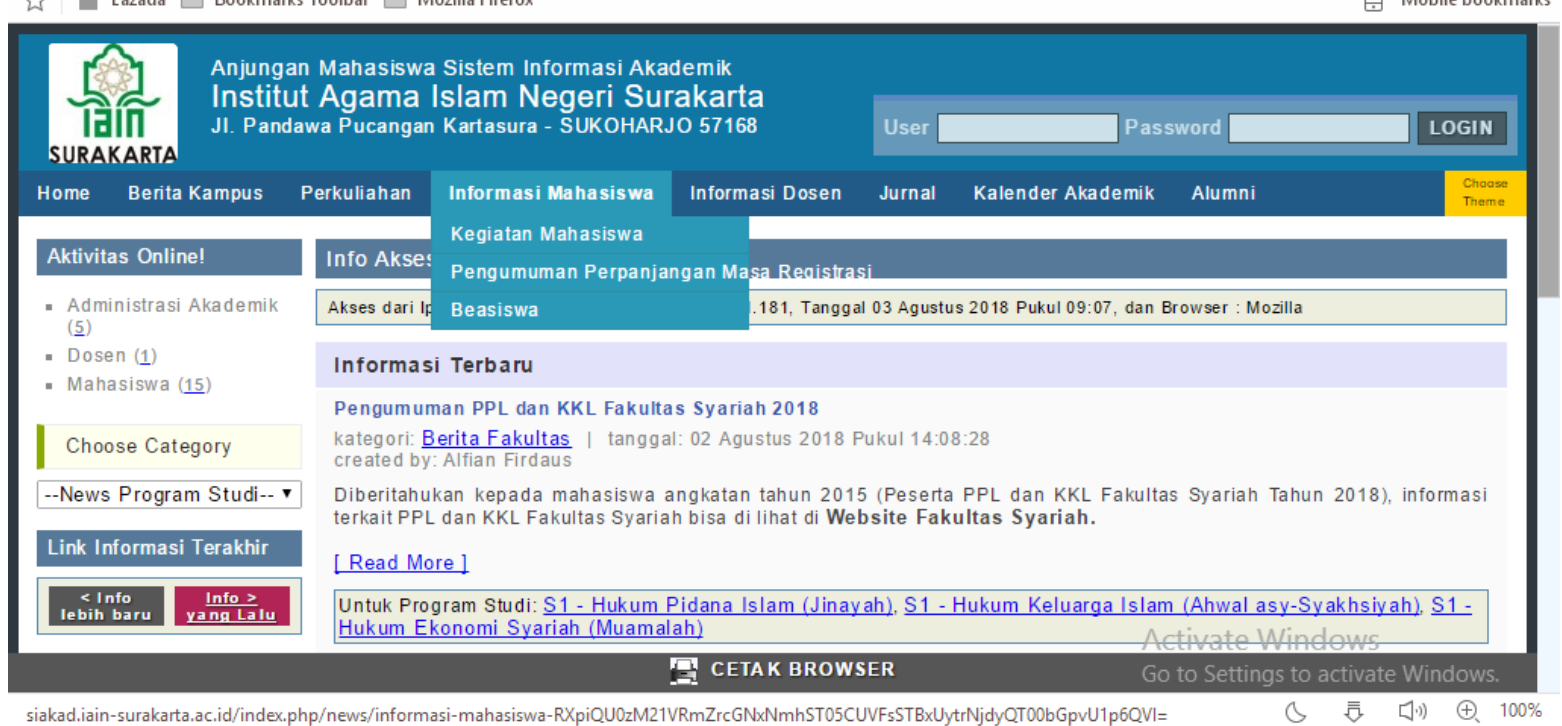
\#

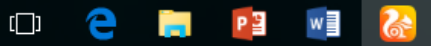

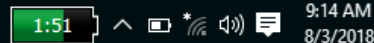

Gambar 4.Tampilan Beranda Informasi Mahasiswa berisi Kegiatan Mahasiswa, Pengumuman Perpanjangan Masa Registrasi dan Beasiswa 


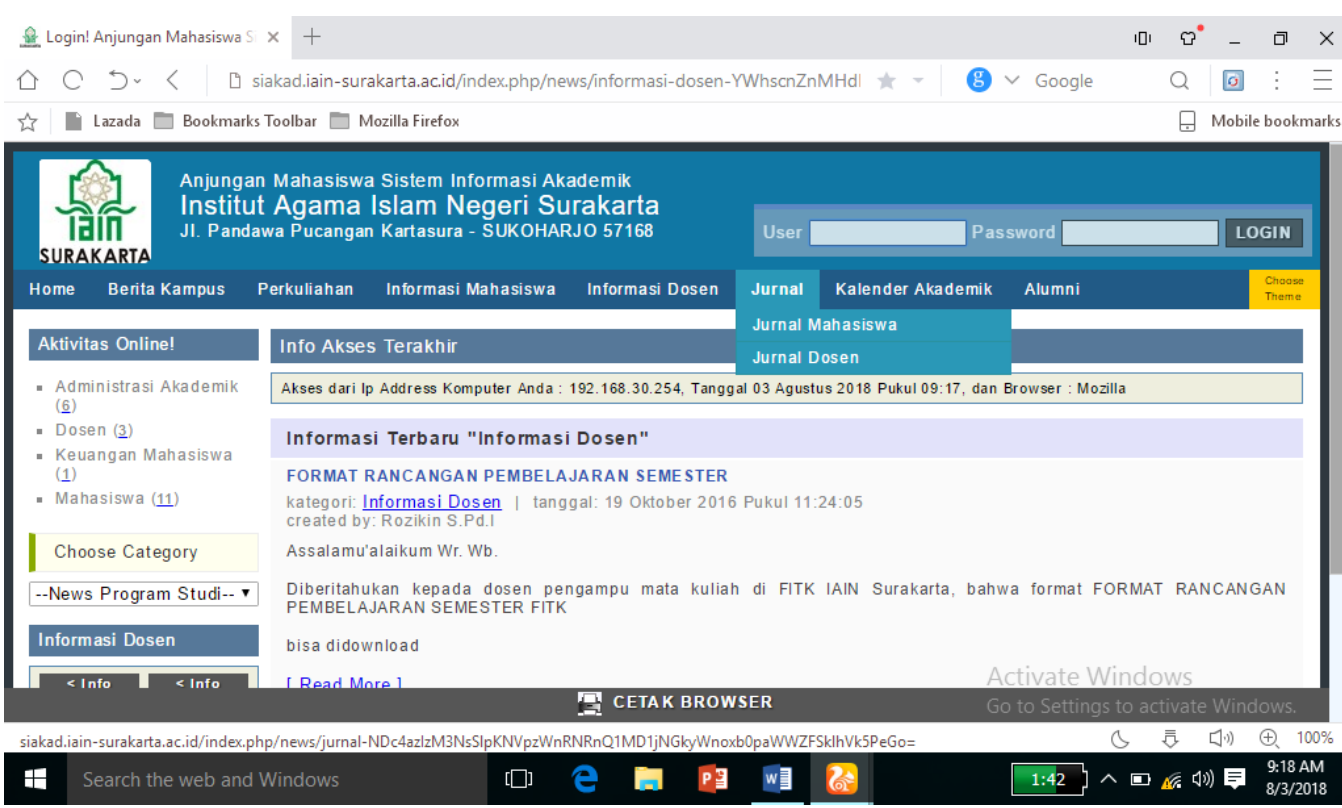

Gambar 5. Tampilan Beranda Jurnal berisi Jurnal Mahasiswa dan Dosen

Bila mahasiswa ingin mengakses masuk SIAKAD maka langkah awalnya harus Log in dengan menggunakan user ID dan Password. Dengan cara ini mahasiswa calon peserta kegiatan praktikum terhubung dengan layanan aplikasi SIAKAD. Setelah masuk pada layanan aplikasi SIAKAD kemudian mahasiswa calon peserta kegiatan praktikum masuk ke dalam aplikasi kerja praktek yang ada didalam menu Akademik. Didalamnya terdapat pilihan manajemen kerja praktek, tambah kelompok, masukkan peserta dalam kelompok, export ke Excel, import +, dan menage daftar pengajuan. Dalam menu manajemen Kerja Praktik berisi semua informasi yang diperlukan dalam hal pendaftaran peserta praktikumn yang terdiri dari tahun akademik, program studi, nama kelompok, nama tempat pratikum yang dituju, alamat tempat praktikan melaksanakan praktikum, no telepon lembaga tempat praktek, program kerja, tanggal mulai, tanggal berakhir dan nama pembimbing.

\section{Validasi Produk Awal.}

Peneliti melakukan uji ahli pada tahap validasi produk awal dengan menunjuk 1 ahli IT dari luar, 1 admin SIAKAD di Fakultas Ilmu Tarbiyah dan Keguruan dan 2 ahli SIAKAD dari PTIPD IAIN Surakarta. Adapun tampilan SIAKAD yang menggunakan online registration system adalah sebagai berikut.

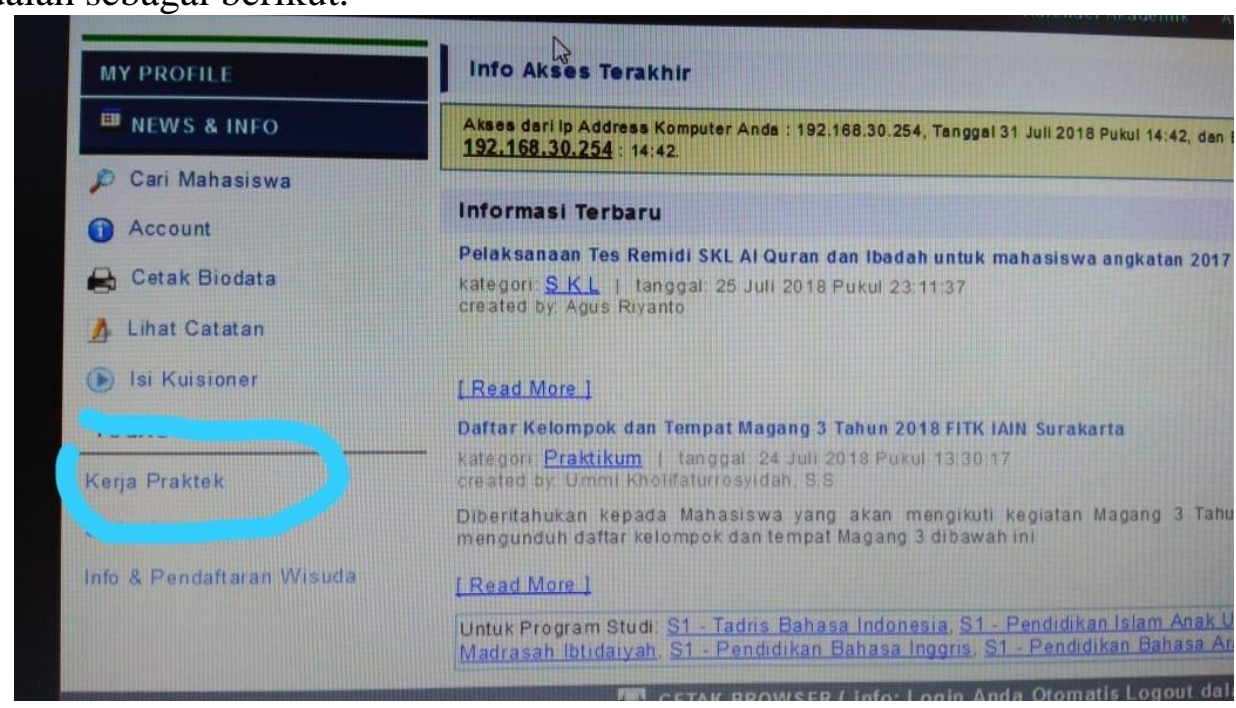




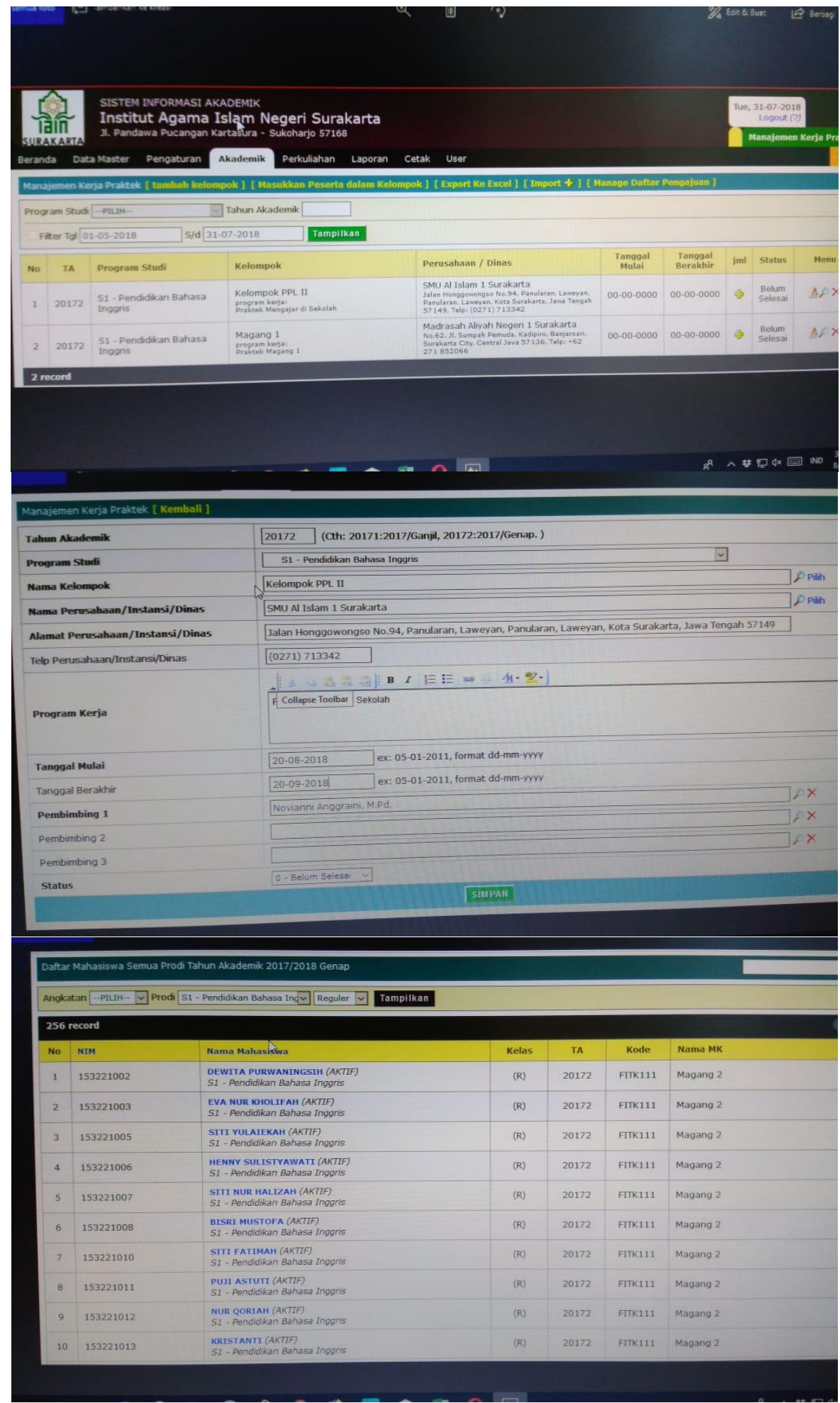

Gambar 6. Tampilan SIAKAD

Penilaian didasarkan pada kemampuan aplikasi online registration system dalam memenuhi tujuan-tujuan khusus dalam hasil dari tahap perencanaaan. Sebelum memberikan penilaian ahli IT diberikan penjelasan tujuan dari pengembang fitur aplikasi layanan pada SIAKAD. Adapun hasil penilaian ahli dapat dilihat dalam Tabel 1 berikut. Table 1. Hasil Uji Ahli APLIKASI siakad terhadap fitur Online Registration System No Aspek Yang dinilai Kurang Cukup Baik Sangat Baik Keterangan Manfaat bagi Admin atau Pengelola 


\begin{tabular}{|c|c|c|c|c|}
\hline No & Aspek Yang dinilai & Kurang Cukup Baik & Sangat Baik & Keterangan \\
\hline 1 & Kemampuan Fitur & & $\mathrm{V}$ & Sangat fleksibel \\
\hline 2 & $\begin{array}{l}\text { Kemampuan dalam } \\
\text { proses pendaftaran } \\
\text { online lebih mudah dan } \\
\text { efektif }\end{array}$ & & V & $\begin{array}{l}\text { Dimungkinkan } \\
\text { untuk } \\
\text { menambah } \\
\text { fungsi layanan } \\
\text { SIAKAD bagi } \\
\text { mahasiswa }\end{array}$ \\
\hline \multicolumn{5}{|c|}{ Manfaat bagi Praktikan } \\
\hline 3 & $\begin{array}{l}\text { Kemampuan } \\
\text { menambah } \\
\text { penggunaan fitur dalam } \\
\text { layanan SIAKAD yang } \\
\text { bisa diakses dimana saja }\end{array}$ & & V & $\begin{array}{l}\text { Dapat } \\
\text { dimungkinkan } \\
\text { mudah } \\
\text { mengakses } \\
\text { layanan } \\
\text { SIAKAD }\end{array}$ \\
\hline 4 & $\begin{array}{l}\text { Kemudahan dalam } \\
\text { mengakses dan } \\
\text { mendaftar sebagai calon } \\
\text { peserta praktikum }\end{array}$ & & V & $\begin{array}{l}\text { Mempermudah } \\
\text { proses } \\
\text { pendaftaran } \\
\text { lebih efisien } \\
\text { secara waktu }\end{array}$ \\
\hline
\end{tabular}

Tabel 2. Uji Ahli Teknologi Informasi dan PTIPD terhadap Online Registration System

\begin{tabular}{|c|c|c|c|}
\hline No. & Kelebihan & No. & Kekurangan \\
\hline 1. & $\begin{array}{l}\text { Terintegrasi dengan SIAKAD } \\
\text { Proses sign up mudah }\end{array}$ & 1. & $\begin{array}{l}\text { Tampilan dashboard masih } \\
\text { tampak kecil }\end{array}$ \\
\hline 2. & Bisa mendaftar secara online & 2. & Pilihan template bawaan terlalu \\
\hline 3. & $\begin{array}{l}\text { Panel Control yang sangat sederhan } \\
\text { dan mudah dimengerti }\end{array}$ & & $\begin{array}{l}\text { sedikit, sehingga tidak langsung } \\
\text { terlihat jelas }\end{array}$ \\
\hline 4. & $\begin{array}{l}\text { Tersedia Navigasi dalam bahasa } \\
\text { Indonesia }\end{array}$ & 3. & $\begin{array}{l}\text { Jika SIAKAD digunakan } \\
\text { bersamaan masih sering lambat }\end{array}$ \\
\hline 6. & $\begin{array}{l}\text { Bisa secara otomatis terdeteksi } \\
\text { kekurangan syarat pendaftaran }\end{array}$ & & dalam layanannya. \\
\hline 7. & $\begin{array}{l}\text { Navigasi admin sederhana, dan mudah } \\
\text { dimengerti }\end{array}$ & & \\
\hline 8. & $\begin{array}{l}\text { Lebih mudah proses verifikasi dan } \\
\text { menyingkat waktu pendaftaran sampai } \\
\text { dengan verifikasi }\end{array}$ & & \\
\hline
\end{tabular}

\section{Pembahasan}

Dari hasil uji ahli, penilaian para ahli yang didapat dari 3 kali FGD menunjukan bahwa rata-rata penilaian menunjukan statistik yang baik dan respon serta catatan yang positif. Secara kualitas aplikasi baru ini dapat dikatakan layak. Oleh karena itu dapat disimpulkan bahwa aplikasi online registration system bisa digunakan secara baik dalam proses pendaftaran calon peserta praktikum khususnya Magang 1, 2, dan 3. Salah satu unsur yang paling berpengaruh dalam proses belajar mengajar adalah kemudahan dalam layanan akademik, baik secara langsung (offline) maupun melalui system teknologi informasi (offline). Layanan administrasi online membantu mahasiswa dan dosen dalam memperlancar komunikasi akdemik. (Santosa et al., 2017) 
Berdasarkan informasi dari beberapa ahli atau pakar IT masih terlihat layanan yang ditawarkan dalam SIAKAD masih cukup sederhana dan kurang dikembangkan. Online Registration System yang menjadi salah satu fitur baru dalam SIAKAD diproyeksikan sebagai salah satu fitur yang akan mempermudah layanan pada mahasiswa terkait pendaftaran sebagai calon peserta praktikan. Disamping itu melalui layanan SIAKAD mahasiswa juga akan lebih mudah dan efektif dalam mencari informasi terbaru dari seluruh civitas akademika di lingkungan FITK khususnya dan IAIN pada umumnya. Hal ini sebagaimana diungkapkan oleh Mutmainna bahwa mahasiswa akan lebih percaya diri dalam merumuskan tujuan pengalaman belajar yang akan mereka peroleh. "students are given the confidence to formulate experimental objectives independently by asking them to position themselves to provide optimal learning to their students"(Mutmainna, 2021)

Hal ini terutama karena alasan SIAKAD yang 24 jam bisa diakses dan kemampuannya menembus batas ruang dan waktu.m meencari informasi terbaru dan terpercaya tentang kegiatan akademik maupun non akademik. Selain itu tambahan layanan online registration system juga yang memungkinkan pengguna mendafar secara online dimanapun mereka berada dengan waktu yang singkat dan efektif.

Sebagai lembaga penyelenggara pendidikan, FITK melakukan upaya layanan yang maksimal kepada users (mahasiswa), hal ini sejalan dengan apa yang diungkapkan oleh Ihsan bahwa perlu adanya KMS (Knowledge Management System) dan ERP (Enterprise Resources Planning) dihasilkan untuk beradaptasi dengan perkembangan manajemen perusahaan. KMS dapat dimanfaatkan untuk memfasilitasi penggunaan ERP. (Ikhsan et al., 2021)

\section{KESIMPULAN}

Berdasarkan dari hasil analisis data, peneliti mendapatakan simpulan bahwa online registration adalah model aplikasi pendaftaran yang lebih efektif untuk mahasiswa dan Unit Laboratrium dan Praktikum FITK IAIN Surakarta dan telah menjadi salah satu fitur baru dalam SIAKAD yang diproyeksikan sebagai salah satu fitur yang akan mempermudah layanan pada mahasiswa terkait pendaftaran sebagai calon peserta praktikan. Disamping itu, melalui layanan SIAKAD, mahasiswa juga akan lebih mudah dan efektif dalam mencari informasi terbaru dari seluruh civitas akademika di lingkungan FITK khususnya yang terkait dengan kegiatan di Unit Laboratorium dan Praktikum.

\section{SARAN}

Berdasarkan hasil penelitian, penilti menyarankan bagi pengembang sistem SIAKAD untuk terus memaksimalkan fungsi baru tersebut dan memberikan interface yang lebih praktis untuk lebih menunjang usabilitas dari system baru tersebut. Selain itu, untuk peneliti yang lain diharapkan untuk bisa melakukan penelitian yang serupa dengan memperhatikan aspek-aspek yang lain seperti pendalaman perihal kualitas system itu sendiri seperti usabilitas sistem, aksesibilitas sistem, dan kualitas informasi yang ada di system tersebut. Selain itu, diharapkan pula untuk melihat dari sudut pandang lain seperti sudut pandang mahasiswa. Oleh karena itu, mahasiswa pun bisa melakukan penelitian serupa dengan sudut pandang mereka sendiri.

\section{DAFTAR PUSTAKA}

Al Fatta, H. (2007). Analisis \& Perancangan Sistem Informasi untuk Keunggulan Bersaing Perusahaan \& Organisasi Modern. Yogyakarta: Penerbit Andi.

Danang, N. H. (2013). Sistem Informasi Akademik SMK KOSGORO 1 Sragen.

Davis, G. B. (1993). Kerangka Dasar Sistem Informasi Manajement. Terjemahan, Seri Management 90.A. Jakarta: PT. Pustaka Binaman Pressindo.

DeLone W. H., McLean E. R., DeLone, \& McLean. (1992). Model of Information Systems 
Success: (D\&M IS Success), (1992).

DeLone W. H., McLean E. R., DeLone, \& McLean. (2003). Model of Information Systems Success: a Ten-Year Update. Journal of Management Information Systems, 19 (4), 9-30.

Ihras, K. R. (2013). Analisis Sistem Informasi Akademik Online Di Universitas Diponegoro Semarang: Universitas Bina Darma.

Ikhsan, M., Anggraeni, R. S., Rarasati, D. A., Raharjo, A., Rahman, A. N., Widodo, A. P., Sediyono, E., Abstrak, S. A., Kunci, K., Sumberdaya, P., Sistem, P. ; \& Pengetahuan, M. (2021). Lensa: Jurnal Kependidikan Fisika. 9(1), 73. https://doi.org/10.33394/j

Janner, S. (2006). Rekayasa Perangkat Lunak.Yogyakarta:Andi

Jogiyanto, H.M. (2005). Sistem Teknologi Informasi Edisi II. Yogyakarta: Penerbit Andi

Kadir, A. (2003). Pengenalan Sistem Informasi. Andi. Yogyakarta.

Ladjamudin, A. B. (2005). Analisis dan Desain Sistem Informasi. Graha Ilmu. Yogyakarta.

Muhammad. (2018). Evaluasi Kinerja Sistem Informasi Akademik Menggunakan IT Balanced Scorecard Pada Universitas Serambi Mekkah Banda Aceh. JURNAL INFORMATIKA UPGRIS, 4 (1).

Mutmainna, M. (2021). Analysis of Prospective Physics Teachers' Ability to Design Experiments in University of West Sulawesi. Lensa: Jurnal Kependidikan Fisika, 9(1), 1. https://doi.org/10.33394/j-1kf.v9i1.3446

Pressman, R.S., (2009), Rekayasa Perangkat Lunak, Buku Satu, diterjemahkan oleh: Harnaningrum L.N., Andi, Yogyakarta.

Raymond, M. J. (2001). Sistem Informasi, Edisi 7 jilid 2. Jakarta: Prenhallindo.

Wibowo, S. E. (2007). Sistem Informasi Akademik Surakarta: Universitas Sebelas Maret Rochaniah, S. Pengembangan Sistem Informasi Online di Sekolah, Kendal: SMP N I Gumuh

Sukarno, M. (2006). Membangun website Dinamis Interaktif dengan PHP-MySQL. Eska Media, Bekasi.

Santosa, R. B., Mahasiswa, P., Pendidikan, J., Inggris, B., \& Surakarta, I. (2017). Motivasi Dalam Pembelajaran Bahasa Inggris: Studi Kasus Motivasi Dalam Pembelajaran Bahasa Inggris: Studi Kasus Pada Mahasiswa Jurusan Pendidikan Bahasa Inggris IAIN Surakarta. In Jurnal Ilmiah DIDAKTIKA Agustus (Vol. 18, Issue 1). http://www.klubguru.com/2-view.php?

Sutabri, T. (2003). Analisa Sistem Informasi. Penerbit Andi Yogyakarta.

Wicaksono, S. A. (2014). ProgramPenjadwalan Perkuliahan Dengan Pendekatan Evolutionary Algorithm (Studi Kasus: Sistem Informasi Akademik (Siakad) Program Teknologi Informasi Dan Ilmu Komputer Universitas Brwijaya), Jurnal Teknologi Informasi dan Ilmu Komputer (JTIIK), 1 (2). 